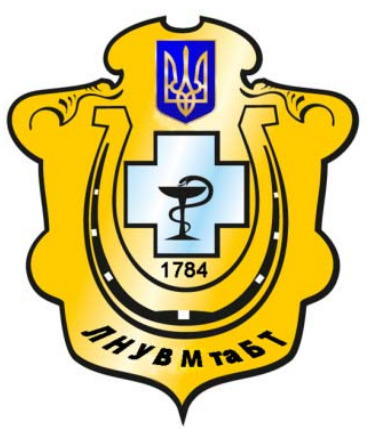

Науковий вісник Львівського національного університету ветеринарної медицини та біотехнологій імені С.3. Гжицького

Scientific Messenger of Lviv National University of Veterinary Medicine and Biotechnologies named after S.Z. Gzhytskyj

doi:10.15421/nvlvet7128

ISSN 2413-5550 print

ISSN 2518-1327 online

$\underline{\text { http://nvlvet.com.ua/ }}$

УДК: 619:636.02:636.08.003

\title{
Репродуктивна функція самок щурів F1 і постнатальний розвиток щуренят F2 за дії різних доз наногерманію цитрату
}

\author{
У.І. Тесарівська ${ }^{1}$, Р.С. Федорук², М.І. Шумська ${ }^{3}$ \\ tesar21@gmail.com
}

${ }^{1}$ Державний контрольний науково-дослідний інститут ветеринарних препаратів та кормових добавок, вул. Донецька, 11, м. Львів, 79000 Україна;

${ }^{1}$ Інститут біології тварин НААН,

вул. Василя Стуса, 38, м. Львів, 79000, Україна;

3 Львівський національний університет ветеринарної медицини та біотехнологій імені С. 3. Гжицького, вул. Пекарська, 50, м. Львів, 79010, Украӥна

\begin{abstract}
Представлено результати досліджень впливу випоювання щурам різних доз “наногерманію” иитрату (НGеЦ) на репродуктивну здатність самок $F_{1}$ і постнатальний розвиток $і$ життєздатність приплоду. Дослідження виконані на самках лабораторних щурів, розділених на 4 групи: 1 - контрольна, 2 - дослідна (10 мкг Ge) , 3 - 20 мкг Ge, 4 - 200мкг Ge/ кг м. m. наногерманію цитрат випоювали самкам від молочного періоду з матерями $F_{0}$ i до запліднення, впродовж вагітності та лактаиії. Визначали показники репродуктивної функції самок иурів, масу гнізда і співвідношення самиів $і$ самок, їх життєздатність, розвиток сенсорно-рухових рефлексів. Встановлено вищі показники запліднюваності самок 4 групи - $100 \%$ проти 85\% у контролі, а також багатоплідності самок усіх дослідних груп на 6,4-17\% та маси гнізда на 3,1 - 15,1\%, середньої маси шуренят на 1,6-3,0\% в 2 групі, на 9,8-11,5\% - в 3-ій, i 2,8-4\%-y 4-ій групах, інтенсивності їх росту за 7 діб у 2 і 3-ій, за 14 діб - у 4, i за 27 діб життя - в 2 та 4-ій групах. Відзначено збільшення кількості народжених самиів у 2 та 4 групах, прискорення розвитку і прояву сенсорних реакцій у щуренят дослідних груп, щяо більше виражено за діі 200 мкг Германію. Збереженість приплоду була високою у всіх групах і становила 100\% у період відлучення на 37 добу життя. Біологічна дія застосованого з водою наногерманію ичитрату більше виражена у иурів, які отримували 20 і 200 мкг Германію.
\end{abstract}

Ключові слова: щури, ріст, маса тіла, наногерманію цитрат, запліднюваність, збереженість, репродуктивна функція, сенсорні реакиї.

\section{Репродуктивная функция самок крыс F1 и постнатальное развитие кры- сят F2 за действия различных доз наногермания цитрата}

\author{
У.И. Тесаривская ${ }^{1}$, Р.С. Федорук ${ }^{2}$ М.И. Шумская ${ }^{3}$ \\ tesar21@gmail.com
}

\footnotetext{
${ }^{1}$ Государственный контрольный научно-исследовательский институт ветеринарных препаратов и кормовых добавок, ул. Донецкая, 11, г. Львов, 79000 Украина;

${ }^{2}$ Институт биологии животных НААН, ул. Василия Стуса, 38, г. Львов, 79000, Украина;

3 Львовский национальный университет ветеринарной медицины и биотехнологий имени С.3. Гжицкого, ул. Пекарская, 50, г. Львов, 79010, Украина
}

Представлены результаты исследований влияния выпойки крысам различных доз «наногерманию» цитрата (HGеЦ) на репродуктивную способность самок F1 и постнатальное развитие и жизнеспособность приплода. Исследования выполне-

\section{Citation:}

Tesarivska, U., Fedoruk, R., Shumska, M. (2016). Reproductive function of rat females and postnatal development of F1 and F2 offspring for the actions of different doses of nanogermanium citrate. Scientific Messenger LNUVMBT named after S.Z. Gzhytskyj, 18, 3(71), 124-129. 
ны на самках лабораторных крыс, разделенных на 4 группьл: 1 - контрольная, 2 - опьтная (10 мкг Ge), 3 - 20 мкг Ge, 4 200 мкг Ge/кг м. т. НGеЦ выпаивали от молочного периода с матерями F0 и до оплодотворения, в течение беременности и лактации. Определяли показатели репродуктивной функиии самок, массу гнезда и соотношение самиов и самок, их жизнеспособность, развитие сенсорно-двигательных рефлексов. Установлень более высокие показатели оплодотворяемости самок 4 группь - 100\% против 85\% в контроле, а также многоплодия самок всех опьтных групп на 6,4 - 17\% и массы гнезда на 3,1 - 15,1\%, средней массы крысят - на 1,6 - 3,0\% во 2 группе, на 9,8 -11,5\% - в третьей, и 2,8 - 4\% - в четвёртой группах, интенсивности их роста за 7 суток во второй и третьей, за 14 суток - в четвёртой, и за 27 суток жизни во второй и четвёртой группах. Отмечено увеличение количества рожденных самцов во 2 и 4 группах, ускорения развития и проявления сенсорных реакций в крысят опытных групп, что более выражено при действии 200 мкг Германия. Сохранность приплода была высокой во всех группах и составила 100\% на 37 сутки жсизи, при завершении молочного периода. Биологическое действие примененного с водой наногерманию ичитрата больше выражено у крыс, получавиих 20 и 200 мкг Германия.

Ключевые слова: крысы, рост, масса тела, наногермания циттрат, фертильность, сохранность, репродуктивная функция, сенсорные реакичи.

\title{
Reproductive function of rat females and postnatal development of F1 and F2 offspring for the actions of different doses of nanogermanium citrate
}

\author{
U. Tesarivska ${ }^{1}$, R. Fedoruk ${ }^{2}$, M. Shumska ${ }^{3}$ \\ tesar21@gmail.com
${ }^{1}$ State Scientific-Research Control Institute of Veterinary Medicinal Products and Feed Additives, Donetsk Str., 11, Lviv, 79000, Ukraine;
${ }^{2}$ Institute of Animal Biology, Vasyl Stus Str., 38, Lviv, 79000, Ukraine;
${ }^{3}$ Lviv national university of veterinary medicine and biotechnologies named after $S$. Gzhytskyj Pekarska Str., 50, Lviv, 79010, Ukraine

The article presents the results of give to drink of female rats the water contained different levels of «nanogermanium» citrate $(\mathrm{NGeC})$ on the reproductive ability of females $F 1$ and postnatal development and viability of offspring. Studies performed on laboratory rats female divided into 4 groups: 1 - control, $2-10 \mu, 3-20 \mu, 4-200 \mu$ of Ge per $\mathrm{kg}$ of body weight. Rat females received the $\mathrm{NGeC}$ starting with suckling (together with F0 mothers) to fertilization and during pregnancy and lactation. Fertility, average litter weight, offspring sex ratio, viability, and development of sensitive and motor reflexes have been investigated. In the female of 4 group higher level of fertility (100\% against $85 \%$ in control) was observed. It has been shown also higher levels of multiple pregnancy, (6.4 $-17 \%)$, average litter weight $(3.1-15.1 \%)$ in all experimental groups and average infant rat weight $(1.6-3.0 \%)-$ in $2-n d$ experimental group, on $9.8-11.5 \%$ - in 3-st experimental group, on $2.8-4 \%$ - 4-th experimental group. The animals of 2 and $3-$ experimental groups are characterized by higher rate of growth up to 7 days of life. The growth intensity was higher also in the rats of 2-nd group up to 14 days of life and in 2-nd and 4-th groups - up to 27 days of life. The increasing of a number of male births in 2 infant 4 experimental groups accelerated development and manifestation of infant sensory reactions in all experimental group have been found. These differences was more expressed when dose of $200 \mathrm{mkg}$ Ge was used. Off spring survival has been high in all groups and was $100 \%$ after weaning at 37 days of life. Biological effect of «nanogermanium» citrate in water form was more pronounced in rats, fed 20 or 200 mkg of Germany.

Key words: rats, height, weight, nanohermanium citrate, fertilization, survival, reproductive function, sensory response.

\section{ВстуII}

Активний розвиток органічної хімії зумовив широке застосування сполук германію в медицині, біології і ветеринарії та став поштовхом для вивчення властивостей цього елементу та його сполук (Lukevic, 1990; Busenka, 2005; Kovalenko, 2012; Vlizlo et al., 2015).

Доклінічні та клінічні випробування різних органічних і комплексних германійвмісних сполук, у тому числі отриманих методом нанотехнологій показали, що вони позитивно впливають на організм, зумовлюючи різносторонні фармакодинамічні ефекти та біологічну дію. Зокрема, органічні та координаційні сполуки германію виявляють протипухлинну, імуномодулюючу, противірусну, нейро-, кардіо-, гепатопротекторну, антигіпоксичну, детоксикаційну, мембранопротекторну дію (Sejfullyna et al., 2003; Stadnyk et al., 2006; Kovalenko, 2012; Dolajchuk et al., 2014). Крім того, германій $є$ необхідним мікроелементом для нор- мальної життєдіяльності організму, що особливо важливо у період його росту та розвитку. Серед інших біологічних властивостей можна відзначити його здатність·забезпечувати перенесення кисню в тканинах, підвищувати імунний статус організму, виявляти антиоксидантну активність, що може мати суттєве значення у період вагітності та лактації (Thayer, 1985; Lukevics and Ignatovich, 2005; Stadnyk et al., 2006; Dolajchuk et al., 2014, 2015). Однак, дослідження впливу цитрату германію на репродуктивну функцію тільки розпочаті (Dolajchuk, 2014; Fedoruk and Hrabko, 2015; Dolajchuk et al., 2015). Особливе наукове зацікавлення зумовлює вивчення біологічної дії цитрату германію, отриманого методом нанотехнології [Patent Ukrai'ny №38391], що має значні переваги - низький рівень токсичності за високої засвоюваності та біодоступності цієї сполуки (Kovalenko, 2012; Dolajchuk et al., 2014, 2015; Fedoruk and Hrabko, 2015). Тому метою досліджень було вивчити особливості репродуктивної здатності самиць щурів F1 та ріст і розвиток їх потом- 
ства за дії різних доз цитрату германію, отриманого на основі використання нанотехнології.

\section{Матеріал і методи досліджень}

Дослідження проводили на лабораторних щурах, які утримувались у віварії ДНДКІ ветпрепаратів і кормових добавок у стандартних умовах з дотриманням біоетичних вимог (Dolajchuk et al., 2014; European convention). У період фізіологічного і статевого дозрівання, запліднення і вагітності та вигодовування потомства у поколінні F0 та F1, тваринам випоювали 3 добовою нормою води різні концентрації наногерманію цитрату (НGeЦ), виготовленого методом нанотехнології та отриманого від ТВО «Наноматеріали i нанотехнології», м. Київ. Щури контрольної та дослідних груп були отримані від самок покоління F1 за аналогічних умов. Вплив цитрату германію на розвиток щуренят вивчали на потомстві від 41 самки щурів та 4 самців. Формування груп самок проводили у віці 3 - 3,5 місяці з масою тіла 182 - 218 г. Тваринам дослідних груп разом з потомством випоювали НGеЦ в наступних дозах: 2 - група (7самок) - 10 мкг / кг м.т., 3 - група (13 самок) - 20мкг/ кг м.т., 4 - група (7 самок) - 200мкг/кг м.т. Контрольні тварини (1 група) (14 самок) мали постійний доступ до питної води. Упродовж дослідження визначали масу тіла самок F1 і приплоду ваговим методом, плодючість за кількістю народженого приплоду, запліднюваність, тривалість вагітності.
Фізіологічні реакції самок F1 та їх потомства F2 оцінювали за їх фізичним станом самок і розвитком (розмір та маса приплоду, краніокаудальний розмір плодів, кількість живих плодів, кількість самок і самців F2, появу первинного волосяного покриву, швидкість розвитку сенсорних рефлексів за періодом відкривання очей. Контролювали масу тіла щурів від народження до 37-денного віку. Визначали відносну інтенсивність росту тварин за методикою С. Броді (Busenko, 20095). У методологічну основу роботи 3 вивчення дії цитрату германію на потомство покладено методичні рекомендації, викладені в довіднику «Доклінічні дослідження ветеринарних лікарських засобів» (Kocjumbas, 2006).

Отриманий цифровий матеріал обробляли загальноприйнятими методами статистичного аналізу на комп'ютері за допомогою програм MS Excel i StatGraphics Plus 2.1.

\section{Результати та їх обговорення}

Аналіз репродуктивної здатності самок контрольної та дослідних $(2,3,4)$ груп вказує на виражений біологічний вплив застосованих доз НGeЦ у щурів. Зокрема, маса тіла самок 2,3,4-ї груп була більшою відповідно на 9,9; 20,1 і 3,4\%, що вплинуло на їх запліднюваність, масу гнізда і чисельність народженого приплоду (табл. 1). Запліднюваність самок відзначалася значними коливаннями в дослідних групах i становила: контроль - 85,7; 2-га група - 85,7; 3-тя $-84,6 ; 4-\mathrm{Ta}-100 \%$.

Таблиия 1

Показники маси тіла і репродуктивної функції самок F1, $\mathrm{M} \pm \mathrm{M}$

\begin{tabular}{|c|c|c|c|c|c|c|}
\hline \multirow{2}{*}{\multicolumn{3}{|c|}{ Показники }} & \multicolumn{4}{|c|}{ Групи } \\
\hline & & & I - контроль & II - 10 мкг & III - 20 мкг & IV - 200 мкГ \\
\hline \multicolumn{3}{|l|}{ Маса тіла, г } & $182,0 \pm 6,04$ & $200,0 \pm 7,87$ & $218,6 \pm 8,84$ & $188,2 \pm 5,56$ \\
\hline \multicolumn{3}{|c|}{ \% від контролю } & 100,0 & 109,9 & 120,1 & 103,4 \\
\hline \multicolumn{3}{|c|}{ Запліднюваність, \% } & 85,7 & 85,7 & 84,6 & 100 \\
\hline \multicolumn{3}{|c|}{ Тривалість вагітності, діб } & $\begin{array}{c}21,8 \pm 0,20 \\
(\mathrm{n}=5)\end{array}$ & $\begin{array}{l}23,00 \pm 0,0 \\
\quad(\mathrm{n}=3)\end{array}$ & $\begin{array}{c}21,8 \pm 0,40 \\
(\mathrm{n}=6)\end{array}$ & $\begin{array}{c}22,0 \pm 0,40 \\
(\mathrm{n}=3)\end{array}$ \\
\hline \multicolumn{3}{|c|}{ \% від контролю } & 100 & 105,5 & 100 & 100,9 \\
\hline \multicolumn{3}{|c|}{ Кількість щуренят на самку } & $9,4 \pm 0,75$ & $10,5 \pm 1,50$ & $10,0 \pm 0,63$ & $11,0 \pm 0,60$ \\
\hline \multicolumn{3}{|c|}{ \% від контролю } & 100 & 111,7 & 106,4 & 117,0 \\
\hline \multirow{6}{*}{$\begin{array}{l}\text { Народи-лось } \\
\text { на самку }\end{array}$} & \multirow{2}{*}{ самців } & гол. & $4,2 \pm 0,50$ & $6,5 \pm 0,50^{*}$ & $4,83 \pm 0,50$ & $6,3 \pm 0,30^{*}$ \\
\hline & & $\%$ & 44,7 & 61,9 & 48,0 & 57,3 \\
\hline & \multicolumn{2}{|c|}{ \% від контролю } & 100 & 154,8 & 114,3 & 150,0 \\
\hline & \multirow{2}{*}{ самок } & гол. & $5,2 \pm 0,54$ & $4,0 \pm 1,00$ & $5,2 \pm 0,50$ & $4,7 \pm 0,67$ \\
\hline & & $\%$ & 55,3 & 38,1 & 52,0 & 42,7 \\
\hline & \multicolumn{2}{|c|}{ \% від контролю } & 100,0 & 76,9 & 100,0 & 90,4 \\
\hline \multicolumn{3}{|c|}{ Середня маса гнізда, г } & 57,5 & 65,1 & 66,2 & 59,3 \\
\hline \multicolumn{3}{|c|}{ \% від контролю } & 100,0 & 113,2 & 115,1 & 103,1 \\
\hline \multicolumn{3}{|c|}{$\begin{array}{l}\text { Краніокаудальний } \\
\text { розмір, см }(\mathrm{n}=10)\end{array}$} & $4,1 \pm 0,08$ & $4,3 \pm 0,16$ & $4,0 \pm 0,15$ & $4,0 \pm 0,20$ \\
\hline \multicolumn{3}{|c|}{ \% від контролю } & 100,0 & 104,9 & 98,3 & 98,3 \\
\hline
\end{tabular}

Примітки: $1-$ у цій і наступних таблицях вірогідність різниць порівняно до контрольної групи враховували* - $<<$ 0,05. 2 - кількість самок F1: I - 14; II - 7; III - 13; IV - 7. 3 - кількість самців F2: I - 59; II - 46; III - 62; IV - 44. самок F2: I - 72; II - 28; III - 68; IV -33 . 
Тривалість вагітності у самок 3 і 4-ї груп зберігалася на рівні контролю, але була більшою на 5,5\% у 2-й групі. Багатоплідність самок за кількістю народжених щуренят була вищою в дослідних групах на 6,4 - 17,0\% порівняно 3 контрольною групою. Отримані результати вказують на стимулюючий вплив застосованих доз НGеЦ на багатоплідність самок щурів, що відзначено нами у самок F0 (Dolajchuk et al., 2014, 2015; Fedoruk and Hrabko, 2015). Випоювання НGеЦ самкам перед заплідненням та у період вагітності впливало на співвідношення самці/самки у гнізді, що більше виражено в 2-й (6,5:4 або 1,6 раза) i в 4-й (6,4:4,7 або 1,3 раза) групах. У самок 3 - ї групи цей коефіцієнт становив $0,93(4,8: 5,2)$, що вказує на відмінності впливу випоювання самкам високих, середніх і малих доз НGeЦ на формування статі у щурів. Краніокаудальний розмір щуренят суттєво не відрізнявся між контрольною і дослідними групами.

Зростання багатоплідності самок 2-ї та 3-ї груп зумовлювало підвищення середньої маси гнізда у цих групах на 13,2 і 15,1\%. Однак, у 4-й групі цей показник був вищим від його значення в контрольній групі лише на $3,1 \%$, що може бути зумовлено найнижчою $(5,4$ г) середньою величиною маси тіла щуреняти в перший день після народження (табл. 2). У той час як у 2, 3, i 4 - й групах цей показник перевищував контроль на 1,6 і 11,5\% (6,2 і 6,8 г відповідно). Характерно, що на 5 - 7 доби середня маса щуренят була най- вищою у 3-й групі (108,5 і 109,8\%), а міжгрупова різниця у 4-й групі порівняно з контрольною зменшилася до 96,2 і 94,7\%.

На 14 добу показник маси тіла щуренят дослідних і контрольної груп зберігався на однаковому рівні. На 27 добу середня маса тіла щуреняти була вищою в 4й групі на 4,1\%, в 2-й - на 2,5\%, а 3-ї зменшилася на $2,9 \%$ порівняно 3 контрольною групою. Отже, можна вважати, що застосована доза в 200 мкг Ge /кг м. т. самок F1 стимулювала їх молочність впродовж 27 діб підсисного періоду. Вищий приріст маси у щуренят 4-ї групи в період $14-27$ діб може також зумовлюватися більшою чисельністю народжених самців у цих групах (див. табл. 1), інтенсивність росту яких $є$ вищою для більшості видів тварин. Це підтверджується і нашими даними щодо вищих показників маси тіла самців, ніж самок щурів як у контрольній, так і у дослідних групах. Однак маса тіла самок 2-4 дослідних груп виявляла менш виражене зниження порівняно 3 самцями (96,9; 93,1 і 94,6\%), ніж контрольної (91,9\%), що може зумовлюватися відмінностями у співвідношенні самці/самки в контрольній і дослідних групах.

Забезпечення оптимальних зоогігієнічних умов утримання, а також годівлі тварин контрольної та дослідних груп сприяло прояву генетичного потенціалу їх росту, розвитку та резистентності організму як самок-матерів, так і приплоду.

Показники життєздатності та фізичного розвитку щуренят F2, M \pm м

Табличя 2

\begin{tabular}{|c|c|c|c|c|c|}
\hline \multirow{2}{*}{\multicolumn{2}{|c|}{ Показники }} & \multicolumn{4}{|c|}{ Групи } \\
\hline & & I - контроль & II - 10 мкг & III - 20 мкг & IV - 200 мкг \\
\hline \multicolumn{6}{|c|}{ Середня маса щуренят: } \\
\hline \multirow{2}{*}{1 день } & $\Gamma$ & $6,1 \pm 0,17$ & $6,2 \pm 0,14$ & $6,8 \pm 0,21 *$ & $5,4 \pm 0,27 *$ \\
\hline & \% від контролю & 100,0 & 101,6 & 111,5 & 88,5 \\
\hline \multirow{2}{*}{5 день } & $\Gamma$ & $10,6 \pm 0,41$ & $10,5 \pm 0,6$ & $11,5 \pm 0,53$ & $10,2 \pm 0,29$ \\
\hline & \% від контролю & 100 & 99,0 & 108,5 & 96,2 \\
\hline \multirow{2}{*}{7 день } & $\Gamma$ & $13,2 \pm 0,37$ & $13,5 \pm 0,25$ & $14,5 \pm 0,59$ & $12,5 \pm 0,5$ \\
\hline & \% від контролю & 100,0 & 103,0 & 109,8 & 94,7 \\
\hline \multirow{2}{*}{14 день } & $\Gamma$ & $23,2 \pm 1,05$ & $23,4 \pm 3,1$ & $22,8 \pm 0,84$ & $22,5 \pm 0,55$ \\
\hline & \% від контролю & 100,0 & 100,9 & 98,3 & 97,0 \\
\hline \multirow{2}{*}{27 день } & $\Gamma$ & $55,4 \pm 2,6$ & $56,8 \pm 0,05$ & $53,8 \pm 1,72$ & $57,7 \pm 1,80$ \\
\hline & \% від контролю & 100,0 & 102,5 & 97,1 & 104,1 \\
\hline \multirow{5}{*}{37 день } & самці & $101,1 \pm 3,23$ & $93,6 \pm 1 \quad 1,43$ & $98,1 \pm 2,62$ & $100,9 \pm 8,0$ \\
\hline & \% від контролю & 100,0 & 92,7 & 97,1 & 99,8 \\
\hline & самки & $92,9 \pm 3,37$ & $90,7 \pm 7,69$ & $91,3 \pm 2,74$ & $95,5 \pm 7,01$ \\
\hline & \% від контролю & 100,0 & 97,6 & 98,3 & 102,8 \\
\hline & \% від самців & 91,9 & 96,9 & 93,1 & 94,6 \\
\hline \multicolumn{2}{|c|}{ Смертність } & 0 & 0 & 0 & 0 \\
\hline \multicolumn{6}{|c|}{ Відкривання очей, \%: } \\
\hline \multicolumn{2}{|r|}{14 день } & 0 & 16,7 & 5,8 & 30,3 \\
\hline \multicolumn{2}{|r|}{15 день } & 43,4 & 55,5 & 54,2 & 65,6 \\
\hline \multicolumn{2}{|r|}{16 день } & 98,8 & 100 & 88,42 & 100 \\
\hline \multicolumn{2}{|r|}{17 день } & 100 & 100 & 100 & 100 \\
\hline \multicolumn{2}{|c|}{$\begin{array}{l}\text { Поява первинного волосяного } \\
\text { покриву на } 4 \text { день, \% }\end{array}$} & 100 & 100 & 100 & 100 \\
\hline
\end{tabular}


Це підтверджується відсутністю загибелі щуренят до відлучення у 37 діб і появою первинного волосяного покриву на $4-5$ добу у всіх щуренят, що відповідає фізіологічним нормам онтогенетичного розвитку цього виду тварин. У той час як відкривання очей у щуренят дослідних груп порівняно 3 контролем розпочалось швидше (14 доба), що більше виражено у щуренят 2-ї групи (16,7\%) і 4-ї групи (30,3\%). Кількісна перевага цього показника в усіх дослідних групах порівняно 3 контролем зберігалася і на $15-$-у добу життя $(54,2 \%-65,6 \%$ проти $43,4 \%$ у контролі), а на 16-ту добу — тільки для 2-ї і 4-ї груп. Ці результати вказують на стимулюючий вплив застосованих доз цитрату германію на формування, розвиток і прояв сенсорних рефлексів у щуренят в ранній постнатальний період.
Отримані дані щодо інтенсивності росту щуренят корелюють 3 показниками середньої маси щуренят в контрольній та дослідних групах. Це вказує на вищий iii рівень у цих тварин у періодах 7 і 27 (2 група) та 5, 14 і 27 діб (4 група) (табл. 3). Важливо відзначити найвищу інтенсивність росту щуренят 4-ї дослідної групи у перші 5 діб - 62,2 \% порівняно з 53,5\% у контрольній групі. Нижча інтенсивність росту цих тварин у періоді 5-7 діб (20,0\%) порівняно з контролем не має фізіологічного пояснення, оскільки у наступні періоди цей показник перевищував контроль на $2,5-5,6 \%$ зі збереженням цієї тенденції міжгрупової різниці для загального показника приросту як у самців, так і у самок. У той час як у 2-й групі вища інтенсивність росту відзначена у періодах 5-7 і 14-27 діб, а у 3-й групі - тільки на 5-7 добу.

Таблиия 3

Інтенсивність росту щуренят покоління F2

\begin{tabular}{|c|c|c|c|c|}
\hline \multirow{2}{*}{ Періоди росту, діб } & \multicolumn{4}{|c|}{ Групи } \\
\hline & I - контроль & II - 10 мкг & III - 20 мкГ & IV - 200 мкг \\
\hline \multicolumn{5}{|c|}{ Середня маса щуреняти, г } \\
\hline $1(\mathrm{M} \pm \mathrm{m})$ & $6,1 \pm 0,17$ & $6,2 \pm 0,14$ & $6,8 \pm 0,21$ & $5,4 \pm 0,27$ \\
\hline \multicolumn{5}{|c|}{ Відносний приріст маси тіла за 2-37 доби, \%: } \\
\hline 5 & 53,5 & 52,1 & 51,8 & 62,2 \\
\hline 7 & 21,7 & 25,4 & 22,6 & 20,0 \\
\hline 14 & 55,0 & 53,1 & 44,6 & 57,5 \\
\hline 27 & 82,1 & 83,5 & 81,0 & 87,7 \\
\hline 37 & 54,6 & 47,25 & 56,2 & 51,2 \\
\hline Загальний приріст, \% & 176,3 & 174,9 & 173,6 & 179,5 \\
\hline
\end{tabular}

Отже, проведений аналіз отриманих результатів досліджень репродуктивної функції самок щурів F1 та постнатального розвитку їх приплоду (F2) вказує на виражену біологічну дію застосованих з водою доз наногерманію цитрату, що більше помітна у тварин 3- i 4-ї груп.

\section{Висновки}

Випоювання цитрату германію характеризувалося такими відмінностями:

- підвищенням багатоплідності самок щурів дослідних груп на 6,4-17,0 \% за кількістю народжених щуренят, а також середнього показника маси гнізда на $3,1-15,1 \%$

- вірогідним зростанням середнього показника маси тіла щуреняти в 3-й групі (20мкг Ge) і зниженням його рівня у 4-й групі ( 200 мкг Ge) на тлі вищої інтенсивності росту цих тварин до 27-ї доби підсисного періоду;

- збільшенням кількості народжених самців у гнізді 2- і 4-ї груп $(6,5$ і 6,3) порівняно як з контрольною $(4,2)$ так і $3-ю(4,8)$ дослідною групами;

- прискоренням розвитку і прояву сенсорних реакцій у щуренят дослідних груп за періодом відкривання очей, що більше виражено у тварин 4-ї групи.

Перспективи подальших досліджень. Будуть з'ясовані біологічні механізми дії HGeЦ на формування i прояв сенсорно-рухових реакцій у різні періоди росту тварин, їх зв'язок з розвитком інших фізіологічних систем.

\section{Бібліографічні посилання}

Vlizlo, V.V., Iskra, R.Ja., Fedoruk, R.S. (2015). Nanobiotehnologii'. Suchasnist' ta perspektyvy rozvytku. Biologija tvaryn. 17, 4, 18-29 (in Ukrainian).

Kocjumbas, I.Ja. (2006). Doklinichni doslidzhennja veterynarnyh likars'kyh zasobiv: Dovidnyk. L'viv: Triada pljus (in Ukrainian).

Dolajchuk, O.P., Fedoruk, R.S., Kaplunenko, V.G. (2014). Fiziologichnyj vplyv nanocytratu germaniju za umov jogo vypojuvannja laktujuchym samkam shhuriv ta i'h pryplodu. Fiziologichnyj zhurnal. 60, 3 (in Ukrainian).

Kovalenko, L.V. (2012). Ocinka stymuljujuchoi' dii' nanoakvahelativ germaniju na pryrodnu rezystentnist' tvaryn. Naukovyj visnyk NUBiP Ukrai'ny. 172 (1), 203-209 (in Ukrainian).

Lukevic, Je.Ja., Gar, T.K., Ignatovich, L.M., Mironov, V.F. (1990). Biologicheskaja aktivnost' soedinenij germanija. Riga: Zinatne.

Patent Ukrai'ny na korysnu model' № 38391. MPK (2006): C07C 51/41, C07F 5/00, C07F 15/00, C07C 53/126 (2008.01), C07C 53/10 (2008.01), A23L 1/00, B82B 3/00. Sposib otrymannja karboksylativ metaliv «Nanotehnologija otrymannja karboksylativ metaliv» [Tekst] / M. V. Kosinov, V. G. Kaplunenko. Opubl. 12.01.2009, Bjul. № 1 (in Ukrainian). 
Stadnyk, A.M., Byc', G.O., Stadnyk, O.A. (2006). Biologichna rol' germaniju $\mathrm{v}$ organizmi tvaryn ta ljudyny. Naukovyj visnyk L'vivs'koi' nacional'noi' akademii' veterynarnoi' medycyny im. S. Z. Gzhyc'kogo. 8, 2, 1, 185-174 (in Ukrainian).

Busenko, O.T. (2005). Tehnologija vyrobnyctva produkcii' tvarynnyctva. K.: Vyshha osvita (in Ukrainian).

Sejfullyna, I.J., Nemjatyh, O.D., Luk'janchuk, V.D., Tkachenko, Je.V. (2003). Farmakologichni efekty germanijevyh spoluk. Odes'kyj medychnyj zhurnal. 6, 111-114 (in Ukrainian).

Fedoruk, P.S., Hrabko, M.I. (2015). Dynamika masy tila i reproduktyvna funkcija samok shhuriv ta zhyttjezdatnist' pryplodu za vypojuvannja riznyh kil'kostej cytratu germaniju. Biologija tvaryn. 17, 3 (in Ukrainian).
Dolaychuk, O.P., Fedoruk, R.S., Kovalchuk, I.I., Kropyvka, S.I. (2015). Physiological and biochemical processes in the organisms of rats when feeding them with different amounts of germanium citrate. The Animal Biology. 17, 2, 50-56.

European convention for the protection of vertebrate animals used for experim. and other scientific purposes. Coun. of Europe, Strasbourg. 1986. pp. 53.

Lukevics, E., Ignatovich, L. (2005). 32Ge Biological Activity of Organogermanium Compounds. Metallotherapeutic Drugs and Metal-Based Diagnostic Agents. The Use of Metals in Medicine. John Wiley \& Sons, Ltd, 279-295.

Thayer, J.S. (1985). Germanium compounds in biological systems. Rev. Silicon, Germanium, Tin, Lead Compd. $8(2-3), 133-155$.

Стаття надійшла до редакиії 28.09.2016 